Sains Malaysiana 49(3)(2020): 653-660

http://dx.doi.org/10.17576/jsm-2020-4903-20

\title{
The Effect of Different Concentrations of Calcium Silicate-Maghemite Coating towards Magnetic Behavior and Bioactivity
}

(Kesan Kepekatan Berbeza Salutan Kalsium Silikat-Magemit kepada Tingkah Laku Magnet dan Aktiviti Bionya)

\author{
Nor HaziRaH MOHD AKHIRUdin, RosLinda SHAMSUdin \& NORINSAN KAMIL OTHMAN*
}

\section{ABSTRACT}

In this study, maghemite $\left(\gamma-\mathrm{Fe}_{2} \mathrm{O}_{3}\right)$ as magnetic nanoparticles (MNPs) material was coated by ceramic materials, calcium silicate $\left(\mathrm{CaSiO}_{3}\right)$ with different concentrations to suit the medical treatment needed. Different concentration was studied to assess the optimal parameter and ability to maintain post-coated superparamagnetic properties of $\gamma-\mathrm{Fe}_{2} \mathrm{O}_{3}$. Concentration of $\mathrm{CaSiO}_{3}$ coated on $\gamma-\mathrm{Fe}_{2} \mathrm{O}_{3}$ was prepared with 3 parameters, 97:3, 95:5, and 93:7\% w/w, respectively. Magnetic properties of $\mathrm{CaSiO}_{3}-\gamma-\mathrm{Fe}_{2} \mathrm{O}_{3}$ were characterized by VSM proceeded with a bioactive study analyzed with FESEM and FTIR after simulated body fluid immersion for 5 days at $37 \pm 1^{\circ} \mathrm{C}$. $\mathrm{CaSiO}_{3}-\gamma-\mathrm{Fe}_{2} \mathrm{O}_{3}$ with concentration 95:5\% w/w exhibit the highest magnetization makes it the most optimum with the average coercivity is 1.6G. FESEM analysis illustrates that the existence of the apatite layer after 5 days of simulated body fluid (SBF) immersion on $\mathrm{CaSiO}_{3}-\gamma-\mathrm{Fe}_{2} \mathrm{O}_{3}$ coating sample, which confirmed the bioactive properties. Therefore, $\mathrm{CaSiO}_{3}-\gamma-\mathrm{Fe}_{2} \mathrm{O}_{3}$ concentration at ratio $95: 5 \% \mathrm{w} / \mathrm{w}$ can be a promising new biomaterial candidate to be applied in the medical field.

Keywords: Bioactive; calcium silicate coating; maghemite; superparamagnetic

\section{ABSTRAK}

Dalam kajian ini, magemit ( $\left.\gamma-\mathrm{Fe}_{2} \mathrm{O}_{3}\right)$ sebagai bahan nanozarah magnetik (MNPs) disalut oleh bahan seramik iaitu kalsium silikat $\left(\mathrm{CaSiO}_{3}\right)$ dengan kepekatan yang berbeza untuk memenuhi keperluan rawatan perubatan. Kepekatan yang berbeza dikaji untuk menentukan parameter yang ideal dan keupayaan untuk mengekalkan sifat superparamagnetik yang dimiliki oleh $\gamma-\mathrm{Fe}_{2} \mathrm{O}_{3}$ selepas proses salutan. Kepekatan $\mathrm{CaSiO}_{3}$ menyalut kepada $\gamma-\mathrm{Fe}_{2} \mathrm{O}_{3}$ disediakan dengan 3 parameter yang berbeza, 97:3\% w/w, 95:5\% w/w dan 93:7\% w/w. Sifat magnetik $\mathrm{CaSiO}_{3}-\gamma-\mathrm{Fe}_{2} \mathrm{O}_{3}$ dicirikan oleh VSM kemudiannya diteruskan dengan kajian sifat bioaktif yang dianalisis menggunakan FESEM dan FTIR selepas direndamkan ke dalam larutan simulasi badan (SBF) selama hari pada $37 \pm 1^{\circ} \mathrm{C}$. $\mathrm{CaSiO}_{3}-\gamma-\mathrm{Fe}_{2} \mathrm{O}_{3}$ dengan kepekatan 95:5\% w/w menunjukkan nilai magnetisasi tertinggi menjadikannya parameter paling optimum dengan purata koersiviti ialah 1.6G. Analisis FESEM menunjukkan kehadiran lapisan apatit selepas 5 hari rendaman SBF pada sampel CaSiO $\mathrm{S}_{3}^{-}$ $\gamma-\mathrm{Fe}_{2} \mathrm{O}_{3}$ mengesahkan sifat bioaktif yang dimiliki. Oleh itu, kepekatan $\mathrm{CaSiO}_{3}-\gamma-\mathrm{Fe}_{2} \mathrm{O}_{3}$ pada nisbah 95:5\% w/w mempunyai potensi untuk dijadikan calon biobahan yang baru untuk diaplikasikan dalam bidang perubatan.

Kata kunci: Bioaktif; magemit; salutan kalsium silikat; superparamagnetik

\section{INTRODUCTION}

Ceramic materials have been researched by scientists for a variety of purposes and have been commonly used in different fields. In vitro studies have shown that ceramic materials have shown excellent bioactivity properties by the ability to form an apatite layer on their surface when in contact with the physiological fluids (Syed Nuzul et al. 2016). Bioactivity studies were conducted using simulated body fluid (SBF) immersion, which was first invented by the Kokubos's team and developed until ions concentration of SBF comparable to human blood plasma (Kokubo 1991; Ohtsuki et al. 1991). $\mathrm{CaSiO}_{3}$-based materials, particularly nanostructure, have high biocompatibility, biodegradability, bioactivity and high drug loading capacity making them ideal for medical used (Zhu et al. 2016).

Magnetic nanoparticles (MNPs) have an ultra-fine size, biocompatible and superparamagnetic properties within the nanoscale that is ideal for medicinal purposes. Small in size, magnetic nanoparticles (MNPs) materials can precisely penetrate to the target area and interact on a cellular (10-100 nm), subcellular (20-250 nm), protein (3-50 nm) or genetic scale $(10-100 \mathrm{~nm}$ (Laurent et al. 2008). Among MNPs materials iron oxide nanoparticles including magnetite $\left(\mathrm{Fe}_{3} \mathrm{O}_{4}\right)$ and maghemite $\left(\gamma-\mathrm{Fe}_{2} \mathrm{O}_{3}\right)$ were the most preferred due to low cost, less toxic and exhibit superparamagnetic properties such as high magnetic saturation moment and almost zero coercivity at room temperature (Sun et al. 2014). Superparamagnetic properties are particularly important for medical application such as for the transmission of drugs and genes transported to the targeted area due to its ability to respond to external magnetic fields (Burinaru et al. 2019). The synthesis of iron oxide nanoparticles has been developed intensely throughout the past decade. Numerous methods have been 
developed to synthesize MNPs including thermal decomposition, sol-gel, co-precipitation, hydrothermal synthesis and the oxidation of MNPs (Nazari et al. 2014).

Nevertheless, due to strong magnetic attraction between particles, iron oxide tends to agglomerate and is therefore not ideal for direct application in the bare surface conditions (Ali et al. 2016). The customization of surface coating on MNPs to the desired requirement can be accomplished by a surface modification which can enhance nanoparticle stabilization (Silva et al. 2016). Over the past years, surface modification of MNPs has been achieved by coating with biocompatible materials such as natural (dextran/ chitosan), synthetic polymers (PEG, PVA), gold and silica-based (Catalano et al. 2017) to improve their properties. Nevertheless, even without the external magnetic field applied, the surface modification on MNPs by polymers resulted in osteoinduction. However, a synthetic polymer such as PEG-coated also have some drawbacks, such as immunogenic activity can also create unwanted immune responses (Guerrini et al. 2018). Wu et al. (2010) stated that new combination of MNPs with ceramic materials could contribute to bone formation in both in vitro and in vivo, and could lead to a slightly high level of proliferation rate (Ngadiman 2015). Above all, as we have seen, there is less analysis paper and research of $\mathrm{CaSiO}_{3}$ as a coating material on $\gamma-\mathrm{Fe}_{2} \mathrm{O}_{3}$. CaSiO itself is a biocompatible ceramic material with excellent bioactivity and superior mechanical strength, making it a promising candidate as one of the coating materials on $\gamma-\mathrm{Fe}_{2} \mathrm{O}_{3}$. Past research papers indicated that $\mathrm{CaSiO}_{3}$ had shown promise as a clinically applied coating product over the years, such load-bearing implant coatings (Xie et al. 2014), titanium implant for hard tissue replacement (Buga et al. 2019) and modified $\mathrm{Zn}$ coating to facilitate osteogenic differentiation (Yu et al. 2017). Moreover, $\mathrm{CaSiO}_{3}$ had considered as potential candidates for artificial bone, when it was implanted into the human body and interacted with the surrounding bone by ion-exchange reaction (Liu et al. 2008).

Therefore, this paper attempts to study and present the ability of $\mathrm{CaSiO}_{3}-\gamma-\mathrm{Fe}_{2} \mathrm{O}_{3}$ coating by the in-vitro technique. In order to do that, performing surface alterations on $\gamma-\mathrm{Fe}_{2} \mathrm{O}_{3}$ using a new material called $\mathrm{CaSiO}_{3}$, the appropriate coating parameter is essential in order to ensure that the superparamagnetic properties can be preserved, which are especially crucial to fulfilling the medical needs in order to reduce side effect to patients. Since it has the potential to be controlled in the absence of an external magnetic field, exhibit superior biocompatibility and the size drops within 50-180 nm (Allaker \& Yuan 2019; Menon et al. 2017). In this study, biomaterial was developed by the synthesizing of $\mathrm{CaSiO}_{3}$ and $\gamma$ - $\mathrm{Fe}_{2} \mathrm{O}_{3}$ manually with less polluting and low-cost reagents, following by a surface modification on $\gamma-\mathrm{Fe}_{2} \mathrm{O}_{3}$ using a new potential coating material which is $\mathrm{CaSiO}_{3}$. Research was conducted with 3 concentrations $\mathrm{CaSiO}_{3}$ to $\gamma-\mathrm{Fe}_{2} \mathrm{O}_{3}, 93: 7 \% \mathrm{w} / \mathrm{w}, 95: 5 \% \mathrm{w} / \mathrm{w}$, and 97:3\% w/w, respectively. Magnetic properties of $\mathrm{CaSiO}_{3}-\gamma-\mathrm{Fe}_{2} \mathrm{O}_{3}$ is a prior study before proceeding to the bioactivity study. Preliminary bioactivity study was conducted in SBF immersion for 5 days to study the growth of apatite formation.

\section{MATERIALS AND METHODS}

PREPARATION OF $\mathrm{CaSiO}_{3}-\gamma-\mathrm{Fe}_{2} \mathrm{O}_{3}$

Nano-structured $\mathrm{CaSiO}_{3}$ was synthesized by adding of calcium nitrate tetrahydrate $\left(\mathrm{Ca}\left(\mathrm{NO}_{3}\right)_{2} \cdot 4 \mathrm{H}_{2} \mathrm{O} 99 \%\right.$ purity) to tetraethyl orthosilicate (TEOS $99 \%$ purity) using the sol-gel method. The homogeneous solution obtained from $\mathrm{CaSiO}_{3}$ was sealed and undergoes an ageing process at $50^{\circ} \mathrm{C}$ for $24 \mathrm{~h}$, followed by opening the seal and drying in the oven for the next $24 \mathrm{~h}$ at $110^{\circ} \mathrm{C}$. The dried gels obtained were moved into an alumina crucible and sintered at $950^{\circ} \mathrm{C}$ for $2 \mathrm{~h}$.

Maghemite nanoparticle $\left(\gamma-\mathrm{Fe}_{2} \mathrm{O}_{3}\right)$ was synthesized by mixing ferrous chloride $\left(\mathrm{FeCl}_{2}\right)$ and ferric chloride $\left(\mathrm{FeCl}_{3}\right)$ at room temperature with ratio $\mathrm{Fe}^{2+} / \mathrm{Fe}^{3+}=1 / 2$. Ten $\mathrm{mL}$ of $1 \mathrm{M} \mathrm{HCl}$ was added to prevent oxidation of $\mathrm{Fe}^{2+}$ and precipitation of $\mathrm{Fe}^{3+}$. Afterwards, $20 \mathrm{~mL}$ of sodium hydroxide $(\mathrm{NaOH})$ was dissolved into the solutions of mixture $\mathrm{Fe}^{2+} / \mathrm{Fe}^{3+}$ salts with continuous stirring resulting in a black precipitate. The black precipitation collected was diluted with deionized water to a volume of $200 \mathrm{~mL}$ and was oxidized under aeration where the solution was boiled while exposed to air for one hour at $95^{\circ} \mathrm{C}$. The oxidation process resulted in the change of colour from black to brown. The $\gamma-\mathrm{Fe}_{2} \mathrm{O}_{3}$ saturated suspension was washed with deionized water and centrifuged four times to remove residue and isolate $\gamma-\mathrm{Fe}_{2} \mathrm{O}_{3}$ suspension and unwanted solution. Finally, $\gamma-\mathrm{Fe}_{2} \mathrm{O}_{3}$ decantation was dried at $40^{\circ} \mathrm{C}$ for 2 days. $\mathrm{CaSiO}_{3}-\gamma-\mathrm{Fe}_{2} \mathrm{O}_{3}$ coating was conducted using covalent bonding method with citric acid as a binder. Then, $\mathrm{CaSiO}_{3}-\gamma-\mathrm{Fe}_{2} \mathrm{O}_{3}$ was milled by a ball mill at $300 \mathrm{rpm}$ for $15 \mathrm{~min}$ (Table 1 ).

\section{simuBIOACTIVE STUDY}

Cylindrical samples of $\mathrm{CaSiO}_{3}-\gamma-\mathrm{Fe}_{2} \mathrm{O}_{3}$ powder is prepared by pressing the paste into the Teflon mould with a height of $12 \mathrm{~mm}$ and a diameter of $6 \mathrm{~mm}$. Samples have been immersed in SBF to study the formation of apatite. Later the SBF solution was removed and then the samples were immersed in acetone for $2 \mathrm{~h}$ and rinsed with deionized (DI) water. Samples were dried in a desiccator for $24 \mathrm{~h}$. SBF solution was prepared according to Kokubo's method. 700 $\mathrm{mL}$ of DI water was measured and poured into a $1 \mathrm{~L}$ beaker while heating to $36.5 \pm 1.0^{\circ} \mathrm{C}$ with continuous stirring. Sodium chloride, sodium hydrogen carbonate, potassium chloride, di-potassium hydrogen phosphate trihydrate, magnesium chloride hexahydrate, calcium chloride, and sodium sulfate were dissolved one by one into DI water. With the addition of the final reagent, tris-hydroxymethyl aminomethane as buffer agent was added slowly into the solution to avoid the sudden increase of $\mathrm{pH}$ value and the 
TABLE 1 . The parameters of $\mathrm{CaSiO}_{3}$ added to $\gamma-\mathrm{Fe}_{2} \mathrm{O}_{3}$ during the coating process

\begin{tabular}{lcc}
\hline Sample & Concentration of $\mathrm{CaSiO}_{3}(\% \mathrm{w} / \mathrm{w})$ & Concentration of $\gamma-\mathrm{Fe}_{2} \mathrm{O}_{3}(\% \mathrm{w} / \mathrm{w})$ \\
\hline Pure $\mathrm{CaSiO}_{3}$ & 100 & 0 \\
$\mathrm{CaSiO}_{3}-\gamma-\mathrm{Fe}_{2} \mathrm{O}_{3}-1$ & 97 & 3 \\
$\mathrm{CaSiO}_{3}-\gamma-\mathrm{Fe}_{2} \mathrm{O}_{3}-2$ & 95 & 5 \\
$\mathrm{CaSiO}_{3}-\gamma-\mathrm{Fe}_{2} \mathrm{O}_{3}-3$ & 93 & 7 \\
Pure $\gamma-\mathrm{Fe}_{2} \mathrm{O}_{3}$ & 0 & 100 \\
\hline
\end{tabular}

SBF solution would become a little turbid and have to stir constantly to obtain a clear solution. Finally, the $\mathrm{pH}$ value of the SBF solution will be adjusted to $7.4 @ 36.5^{\circ} \mathrm{C}$ by adding hydrochloric acid slowly for the SBF solution able to imitate human blood plasma perfectly (Kokubo 1991).

\section{RESULTS AND DISCUSSION}

Magnetic properties of pure $\gamma-\mathrm{Fe}_{2} \mathrm{O}_{3}$ and $\mathrm{CaSiO}_{3}$ coating on $\gamma-\mathrm{Fe}_{2} \mathrm{O}_{3}$ with ratio $97: 3 \% \mathrm{w} / \mathrm{w}, 95: 5 \% \mathrm{w} / \mathrm{w}$ and $93: 7 \%$ w/w were measured using Vibrating Sample Magnetometer (VSM) at room temperature. Based on VSM analysis, superparamagnetic properties of nanomaterials can be proved with a single magnetic domain, exhibit negligible hysteresis loss and passes through its origin and above all, superparamagnetic properties verified the nano-size of the particles (Gopal \& Joe 2017). According to Figure 1 (pure $\left.\gamma-\mathrm{Fe}_{2} \mathrm{O}_{3}\right)$ and Figure $2\left(\mathrm{CaSiO}_{3}-\gamma-\mathrm{Fe}_{2} \mathrm{O}_{3}\right)$ coated with different ratios 97:3\% w/w, 95:5\% w/w and 93:7 \% w/w, both figures show magnetization curves indicating superparamagnetic properties of the nanoparticles (Khodabakhshi \& Bahari 2017).

Pure $\gamma-\mathrm{Fe}_{2} \mathrm{O}_{3}$ displayed magnetization $48.88 \mathrm{emu} / \mathrm{g}$ lower than the corresponding bulk $74 \mathrm{emu} / \mathrm{g}$ (Shokrollahi 2017 ) with coercivity value (Hc) $0.7 \mathrm{G}$. In the past experiment reported that $31.18 \mathrm{emu} / \mathrm{g}$ magnetization of $\gamma-\mathrm{Fe}_{2} \mathrm{O}_{3}$ nanoparticles produced by chemical coprecipitation at room temperature has been proved and achieved (Nurdin et al. 2014). Although all the samples exhibited superparamagnetic properties, with zero coercivity and remanence, $\mathrm{CaSiO}_{3}-\gamma-\mathrm{Fe}_{2} \mathrm{O}_{3}-2(95: 5 \% \mathrm{w} / \mathrm{w})$ show the highest magnetization with $20.97 \mathrm{emu} / \mathrm{g}$. The coercivity of sample $\mathrm{CaSiO}_{3}-\gamma-\mathrm{Fe}_{2} \mathrm{O}_{3}(95: 5 \% \mathrm{w} / \mathrm{w})$ nearest to zero with $0.4 \mathrm{G}$ considered the ideal sample compare to the other ratios after the surface alteration since zero coercivity was the most favours to be controlled by external field particularly for a medical purpose (Wu et al. 2010). The agglomeration of $\gamma-\mathrm{Fe}_{2} \mathrm{O}_{3}$ can be minimized by coating and preserving the superparamagnetic properties makes them desirable to further applied for medicinal purposes. Subsequently, the appropriate amount of $\mathrm{CaSiO}_{3}$ added to $\gamma-\mathrm{Fe}_{2} \mathrm{O}_{3} \mathrm{~s}$ had a strong influence on the behaviour of the magnetic properties. Superparamagnetic properties are essential for medical purposes because, by demonstrating that particular behaviour, drugs can be quickly delivered and induced at precisely the specified time by self-heating, and can migrate along the field of attraction in the capillary blood system (Ali et al. 2016). Also, with surface alteration on $\gamma-\mathrm{Fe}_{2} \mathrm{O}_{3}$ by $\mathrm{CaSiO}_{3}$, the high aggregation proneness of $\gamma-\mathrm{Fe}_{2} \mathrm{O}_{3}$ may decrease, surface oxidation exposure can be protected, and blood circulation time may increase (Matos et al. 2019).

Superparamagnetic properties functioning in the medicinal field by tracking the tumour cells as they can be identified with Magnetic Resonance Imaging (MRI) and destroy them by releasing drugs or magnetic, diagnosing and further monitoring early stages of endothelial inflammation, one of the early symptoms of cardiovascular diseases. Above all, superparamagnetic properties are injectable into tumour region, however, following this, not only cancerous cell would be destroyed, even the healthy cells could be affected (Dulińska-Litewka et al. 2019). Thus, in order to prevent and minimize the damage to the surrounding healthy cells, biocompatible $\mathrm{CaSiO}_{3}-\gamma-\mathrm{Fe}_{2} \mathrm{O}_{3}$ coating was performed with appropriate parameter while ensuring superparamagnetic properties were maintained, the aggregation of $\gamma-\mathrm{Fe}_{2} \mathrm{O}_{3}$ decreased and the $\mathrm{CaSiO}_{3}-\gamma-\mathrm{Fe}_{2} \mathrm{O}_{3}$ coating remained stable for prolonged usage.

Theoretically, with the increasing saturation magnetization, the size of nanoparticles then will be decreased. 95:5\% w/w ratio demonstrated the highest magnetization curves, with the smallest particle size among other ratios $(93: 7 \% \mathrm{w} / \mathrm{w}, 97: 3 \% \mathrm{w} / \mathrm{w})$. The results obtained from VSM analysis of $\mathrm{CaSiO}_{3}-\gamma-\mathrm{Fe}_{2} \mathrm{O}_{3}$ with ratio 95:5\% $\mathrm{w} / \mathrm{w}$ are in accordance to the study conducted by Ngadiman et al. (2015) which reported that the optimum parameter of $\gamma-\mathrm{Fe}_{2} \mathrm{O}_{3}$ nanoparticles was $5 \% \mathrm{w} / \mathrm{w}$ for tissue engineering scaffold. It could be therefore summed up that in this study, $\mathrm{CaSiO}_{3}-\gamma-\mathrm{Fe}_{2} \mathrm{O}_{3}$ with ratio $95: 5 \% \mathrm{w} / \mathrm{w}$ has the potential for medical application. Hence, $\mathrm{CaSiO}_{3}-\gamma-\mathrm{Fe}_{2} \mathrm{O}_{3}$ with ratio 95:5\% w/w was chosen to proceed evaluated in vitro study by immersion into SBF solution containing ion concentrations nearest to human blood plasma. The bioactivity of the sample was examined by the formation of an apatite layer on the surface of $\mathrm{CaSiO}_{3}-\gamma-\mathrm{Fe}_{2} \mathrm{O}_{3}$. The sample was immersed in SBF for 5 days for preliminary bioactive study.

For comparison of the bioactive study, $\mathrm{CaSiO}_{3}-\gamma-\mathrm{Fe}_{2} \mathrm{O}_{3}$ sample without SBF and 5 days immersion were analyzed using Field Emission Scanning Electron Magnetometer (FESEM) and Fourier-Transform Infrared Spectroscopy (FTIR). Whereas, Figure 3 shows VSM analysis of $\mathrm{CaSiO}_{3}$ $\gamma-\mathrm{Fe}_{2} \mathrm{O}_{3}$ in a physiochemical fluid of SBF immersion after 


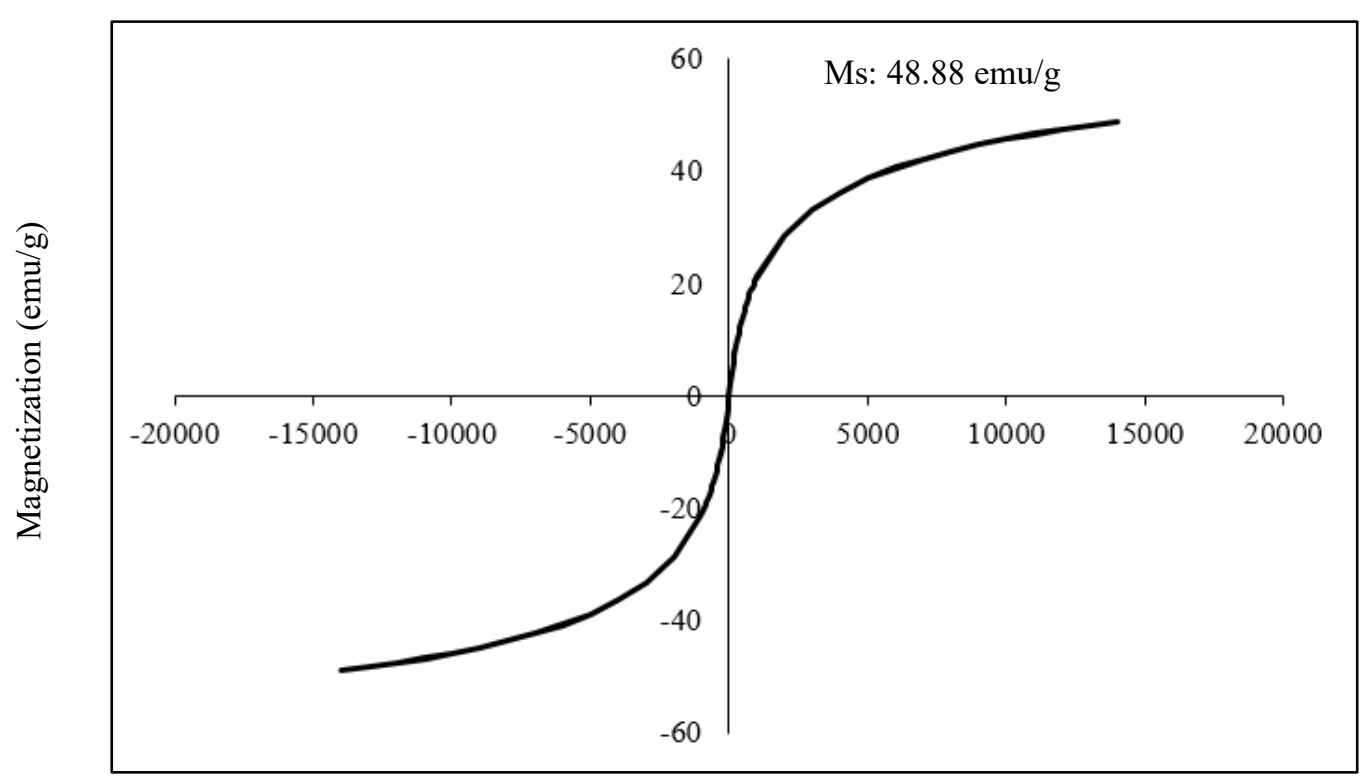

Field (G)

FIGURE 1. Superparamagnetic properties of pure $\gamma-\mathrm{Fe}_{2} \mathrm{O}_{3}$ before coated by $\mathrm{CaSiO}_{3}$ through VSM analysis

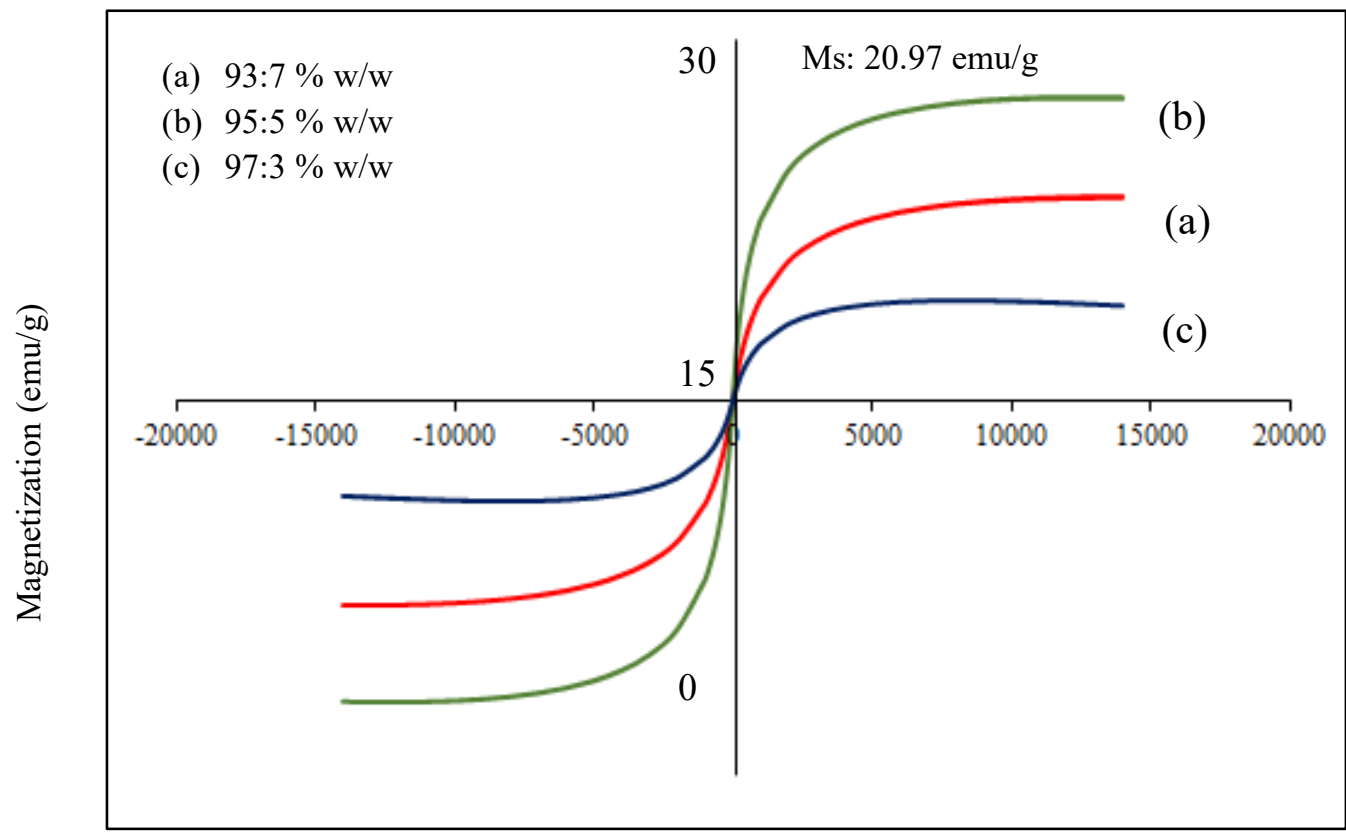

Field $(\mathrm{G})$

FIGURE 2. Magnetization curves through VSM analysis $\mathrm{CaSiO}_{3}-\gamma-\mathrm{Fe}_{2} \mathrm{O}_{3}$ (a) $93: 7 \% \mathrm{w} / \mathrm{w}$ (b) $95: 5 \% \mathrm{w} / \mathrm{w}$ and (c) $97: 3 \% \mathrm{w} / \mathrm{w}$

1,3 , and 5 days to predicted superparamagnetic behaviour prior in-vivo used. Analysis displayed the magnetization saturation was decreased along with the immersion period. After 5 days SBF immersion, magnetization was dropping to $0.21 \mathrm{emu} / \mathrm{g}$. The previous finding stated that magnetization value will be rising if coated-shell $\left(\mathrm{CaSiO}_{3}\right)$ degraded first than $\gamma-\mathrm{Fe}_{2} \mathrm{O}_{3}$ (Rabel et al. 2019). The functional group of the interaction $\mathrm{CaSiO}_{3}-\gamma-\mathrm{Fe}_{2} \mathrm{O}_{3}$ was identified by FTIR. The spectrum shows the functional group exists in the sample without SBF (Figure 4(a)) and with 5 days of SBF immersion (Figure 4(b)). The absorption peak at $1630 \mathrm{~cm}^{-1}$ identified as hydroxyl group $(\mathrm{O}-\mathrm{H})$ of water (Lee et al. 2017). Meanwhile, peak at $882 \mathrm{~cm}^{-1}$ reported as pure $\gamma-\mathrm{Fe}_{2} \mathrm{O}_{3}$ and peak at $1370 \mathrm{~cm}^{-1}, 1630 \mathrm{~cm}^{-1}, 1409 \mathrm{~cm}^{-1}$ were owed to $\mathrm{O}-\mathrm{H}$ bonding vibration.

The peak in the range of $400 \mathrm{~cm}^{-1}$ to $800 \mathrm{~cm}^{-1}$ corresponds to be the stretching of Fe-O bonds (Gopal \& Joe 2017). However, based on FTIR analysis, the increasing 


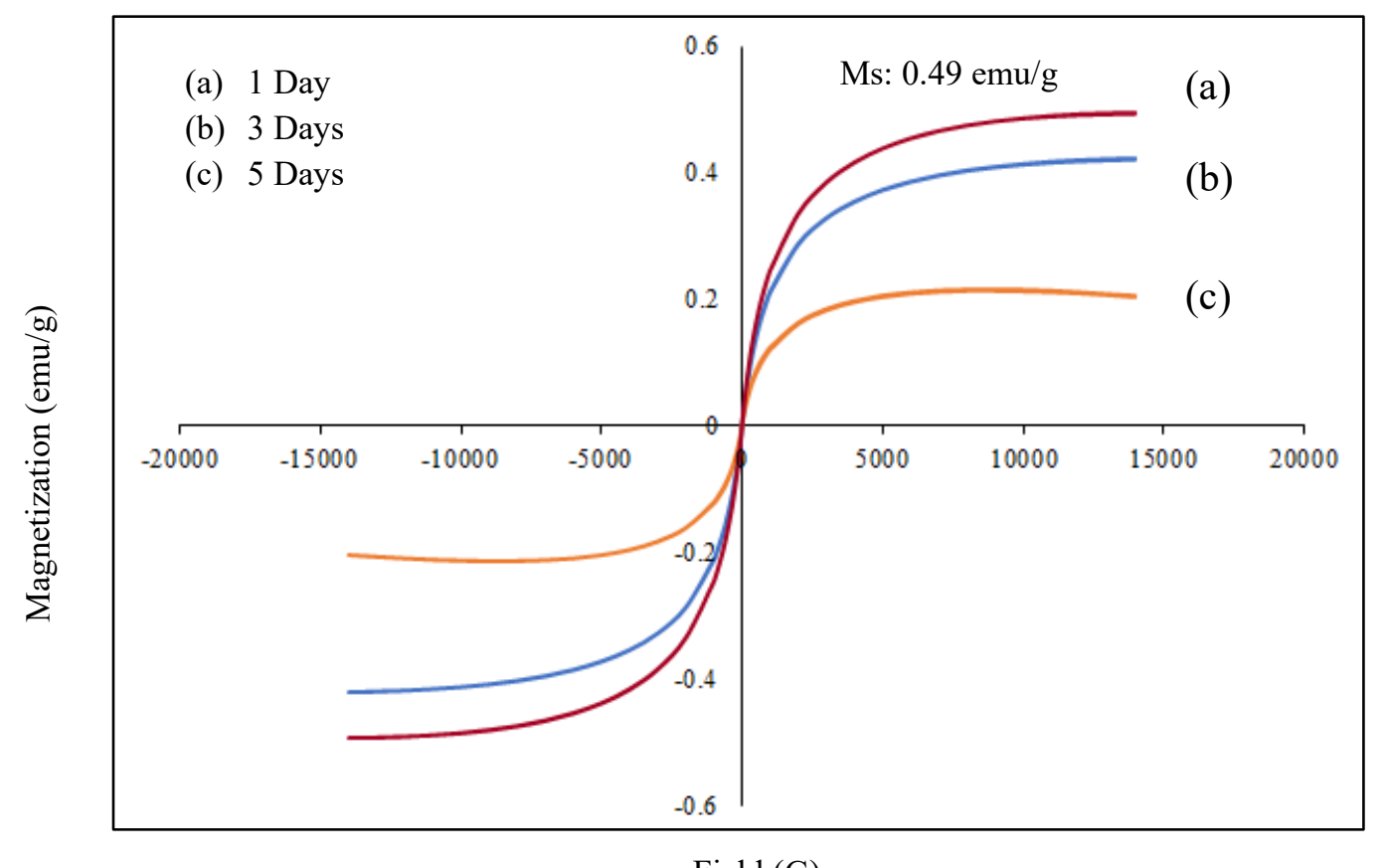

Field (G)

FIGURE 3. Magnetization curve of (a) day 1 SBF immersion, (b) day 3 SBF immersion and (c) day 5 SBF immersion

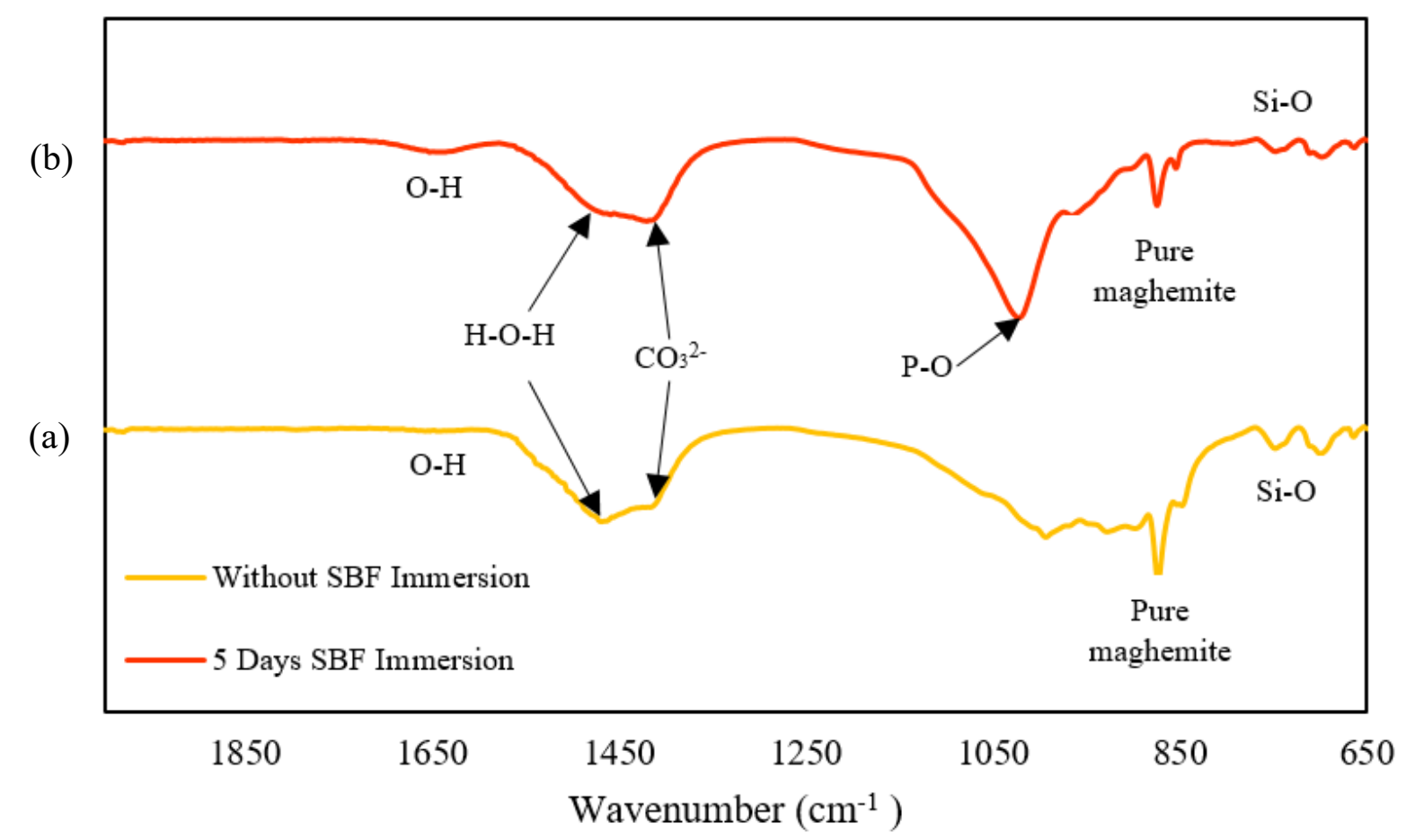

FIGURE 4. (a) $\mathrm{CaSiO}_{3}-\gamma-\mathrm{Fe}_{2} \mathrm{O}_{3}$ without $\mathrm{SBF}$ immersion and (b) after 5 days $\mathrm{SBF}$ immersion

sharp peak at $1024 \mathrm{~cm}^{-1}$ was identified for $\mathrm{CaSiO}_{3}-\gamma-\mathrm{Fe}_{2} \mathrm{O}_{3}$ sample with 5 days of SBF immersion compared to sample without SBF immersion where this peak is corresponding to the presence of $\mathrm{P}-\mathrm{O}$ group. The increasing intensity values of the $\mathrm{P}-\mathrm{O}$ group is attributed to the reaction between phosphate ions $\left(\mathrm{PO}_{4}^{3-}\right)$ and calcium ions $\left(\mathrm{Ca}^{2+}\right)$ during the formation of the apatite layer (Ismail et al. 2016).
Additionally, this peak will gradually increase with the more prolonged SBF immersion as it resulted from the growing of the apatite layer.

In previous work, researchers have a high interest in calcium silicate as a coating material due to its's ability to increase chemical stability in a physiological environment (Li et al. 2016). Morphology of $\mathrm{CaSiO}_{3}-\gamma-\mathrm{Fe}_{2} \mathrm{O}_{3}$ was 

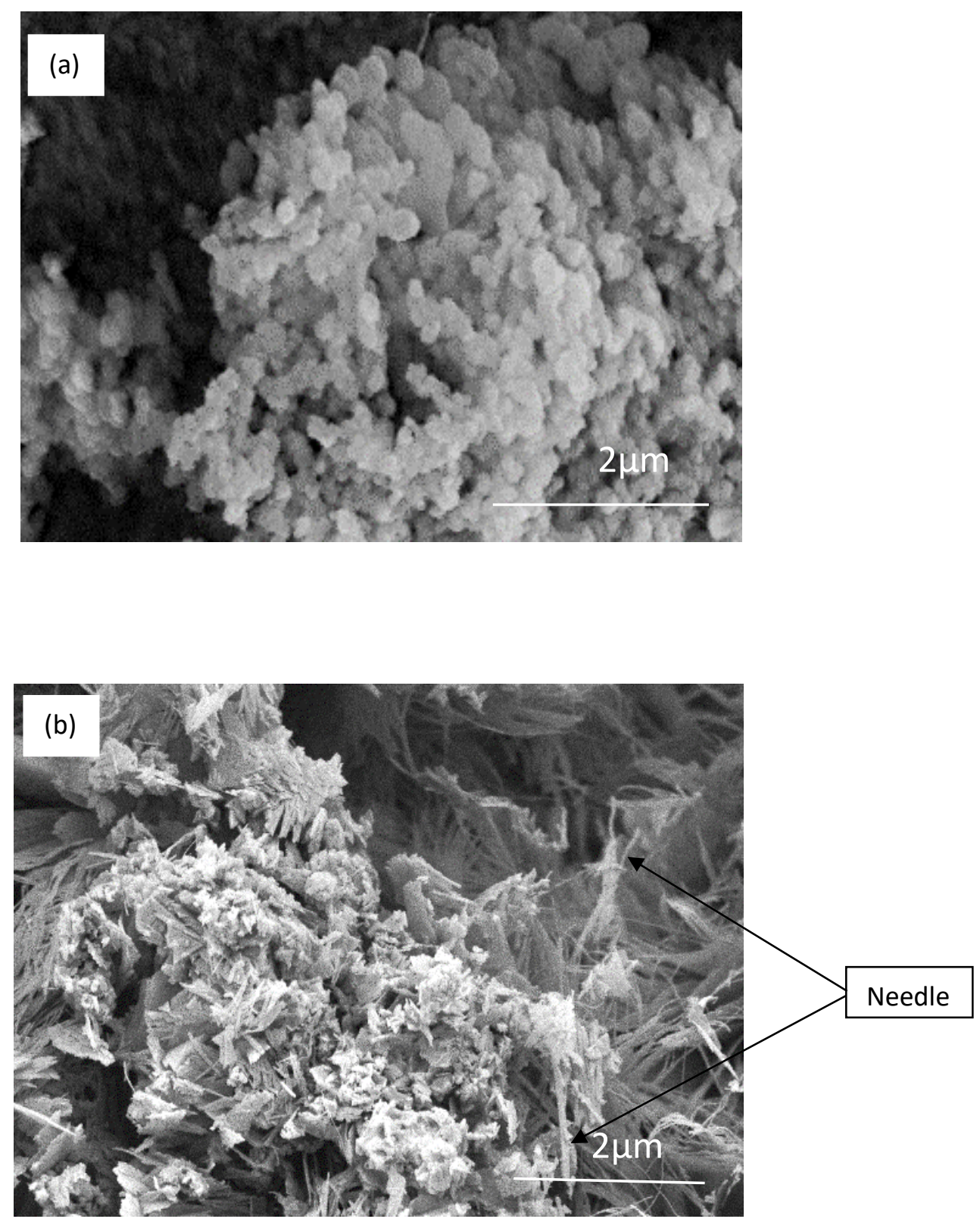

FIGURE 5. FESEM images of $\mathrm{CaSiO}_{3}-\gamma-\mathrm{Fe}_{2} \mathrm{O}_{3}$ (a) before soaking in SBF solution and (b) after 5 days soaking

analyzed by Field Emission Scanning Electron Microscopy (FESEM) analysis. Bioceramic materials will form crystalline calcium phosphate such as active biological hydroxyapatite layer (HA) on the surface of the material when immerses into the SBF solution which contained ions concentration similar to human blood plasma (Abdul Azam et al. 2018).

It was observed that, in Figure 5, regardless of the coating process conducted, the amount of iron $\left(\mathrm{Fe}^{+}\right)$has remained the same, as well the spherical shape of $\gamma-\mathrm{Fe}_{2} \mathrm{O}_{3}$. The $\mathrm{CaSiO}_{3}-\gamma-\mathrm{Fe}_{2} \mathrm{O}_{3}$ 95:5\% w/w with 5 days SBF immersion shown needle-type morphology as according to Damas et al. (2019) which indicates the absences of apatite layer. Figure 5(a) shows a smooth surface unlike Figure 5(b) which shows rough needle look-alike structure which recognized as the apatite layer was formed due to
$\mathrm{Ca}^{2+}$ ions release from $\mathrm{CaSiO}_{3}$ after interaction with $\mathrm{SBF}$ solution (Zamarron et al. 2009). The needle-like structures or apatite layer presence on $\mathrm{CaSiO}_{3}-\gamma-\mathrm{Fe}_{2} \mathrm{O}_{3}$ 's surface will grow and becoming coral-like structures eventually more crystalline as the immersion period getting longer (Ismail et al. 2016).

The EDS spectra analysis shows that the $\mathrm{Ca} / \mathrm{P}$ ratio for 5 days SBF soaking is about 3.35. The amount of $\mathrm{Ca} / \mathrm{P}$ will further decrease with increasing immersion period and the value can reach approximately 1.67 after 10 days SBF immersion which conveyed ultimately a very thick apatite layer (Giannoulatou et al. 2018). EDS analysis demonstrates that the concentration of $\mathrm{Fe}$ ions was decreased after coating from 6.6 to 3.5 at $\%$ which can be assumed that $\mathrm{CaSiO}_{3}$ was successfully encapsulated $\gamma-\mathrm{Fe}_{2} \mathrm{O}_{3}$ nanoparticles. 
Therefore, it can be concluded that results obtained from FESEM analysis are in tallies with FTIR analysis. As the $\mathrm{CaSiO}_{3}-\gamma-\mathrm{Fe}_{2} \mathrm{O}_{3}$ coating sample able to form apatite layer on its surface through morphology study and the peak of the $\mathrm{P}-\mathrm{O}$ bond was increased after 5 days SBF immersion. Hence, through the bioactive study by immersed $\mathrm{CaSiO}_{3}$ $\gamma-\mathrm{Fe}_{2} \mathrm{O}_{3}$ into SBF solution, the ability of apatite to form on $\mathrm{CaSiO}_{3}-\gamma-\mathrm{Fe}_{2} \mathrm{O}_{3}$ 's surface indicates that the coating process was successful by exhibiting good bioactivity.

\section{CONCLUSION}

Potential of $\mathrm{CaSiO} 3-\gamma-\mathrm{Fe}_{2} \mathrm{O}_{3}$ coating is considered to be successful with the ability to form apatite on the surface layer through in vitro study and proven good bioactivity. Superparamagnetic properties of $\gamma-\mathrm{Fe}_{2} \mathrm{O}_{3}$ can be preserved even after surface modification completed by $\mathrm{CaSiO}_{3}$ proved that the presence of $\mathrm{CaSiO}_{3}$ did not affect the behaviour of $\gamma-\mathrm{Fe}_{2} \mathrm{O}_{3}$. All the data provided indicate that the concentration of $\mathrm{CaSiO}_{3}$ coating plays a fundamental role in ensuring the performance of $\gamma-\mathrm{Fe}_{2} \mathrm{O}_{3}$ accordingly. $\mathrm{CaSiO}_{3}-\gamma-\mathrm{Fe}_{2} \mathrm{O}_{3}$ with ratio 95:5\% w/w demonstrates the most optimal compared to $93: 7 \% \mathrm{w} / \mathrm{w}$ and $97: 3 \% \mathrm{w} / \mathrm{w}$ with a better superparamagnetic property. We believe that the results obtained from this study, $\mathrm{CaSiO}_{3}-\gamma-\mathrm{Fe}_{2} \mathrm{O}_{3}$ coating will be functioning at the upmost during medical treatment and can be bonded to the existed bone even shorter as artificial bone. The biocompatibility of $\mathrm{CaSiO}_{3}$ $\gamma-\mathrm{Fe}_{2} \mathrm{O}_{3}$ can be further studied through cytotoxicity tests to enhance and strengthen the potential for medical treatments.

\section{ACKNOWLEDGEMENTS}

The authors would like to acknowledge and extend sincere appreciation for the fund provided during this research was conducted No Grant: TRGS/2/2014/UKM/02/4/3, DIP2018-032, ST-2018-015 and Centre of Research and Instrumentation (CRIM), UKM for the facilities provided.

\section{REFERENCES}

Abdul Azam, F.A., Ismail, H., Shamsudin, R., Ng, M.H. \& Abdul Hamid, M.A. 2018. Pengaruh suhu sinteran terhadap kebioaktifan wolastonit daripada abu sekam padi dan batu kapur. Sains Malaysiana 47(4): 819-827.

Ali, A., Zafar, H., Zia, M., Ul Haq, I., Phull, A.R., Ali, J.S. \& Hussain, A. 2016. Synthesis, characterization, applications, and challenges of iron oxide nanoparticles. Nanotechnology, Science and Applications 9: 49-67.

Allaker, R.P. \& Yuan, Z. 2019. Nanoparticles and the control of oral biofilms. Nanobiomaterials in Clinical Dentistry 2019: 243-275.

Buga, C., Hunyadi, M., Gacsi, Z., Hegedus, C., Hakl, J., Schmidt, U., Ding, S.J. \& Csik, A. 2019. Calcium silicate layer on titanium fabricated by electrospray deposition. Materials Science \& Engineering 98: 401-408.

Burinaru, T.A., Volmer, M., Avram, M., Tucureanu, V., Avram, A., Tincu, B., Marculescu, C., Matei, A. Marinescu, R. \& Militaru, M. 2019. Antibody functionalized magnetic nanoparticles for circulating tumor cells detection and capture using magnetophoresis. IOP Conference Series: Materials Science and Engineering 485(1): 1-6.

Catalano, E., Miola, M., Ferraris, S., Novak, S., Oltolina, F., Cochis, A., Prat, M., Verne, E., Rimondini, L. \& Follenzi, A. 2017. Magnetite and silica-coated magnetite nanoparticles are highly biocompatible on endothelial cells in vitro Biomedical Physics \& Engineering Express 3(2): 025015.

Damas, J.O., Moscardini, S.B., Oliveira, L.R., Silva, R.R.D., Nassar, E.J., Faria, E.H.D., Ciuffi, K.J., Ribeiro, S.J.L. \& Rocha, L.A. 2019. Effect of silica coating on the catalytic activity of maghemite nanoparticles impregnated into mesoporous silica matrix. Materials Chemistry and Physics 225: $145-152$.

Dulińska-Litewka, J., Łazarczyk, A., Hałubiec, P., Szafranski, O., Karnas, K. \& Karewicz, A. 2019. Superparamagnetic iron oxide nanoparticles-Current and prospective medical applications. Materials 12(4): 1-26.

Giannoulatou, V., Theodorou, G.S., Zorba, T., Kontonasaki, E., Papadopoulou, L., Kantiranis, N., Chrissafis, K., Zachariadis, G. \& Paraskevopoulou, K.M. 2018. Magnesium calcium silicate bioactive glass doped with copper ions: Synthesis and in vitro bioactivity characterization. Journal of NonCrystalline Solids 500: 98-109.

Gopal, S.V. \& Joe, I.H. 2017. Bioactivity of superparamagnetic maghemite nanorods capped with dl-alanine. Journal of Molecular Liquids 234: 382-390.

Guerrini, L., Alvarez-Puebla, R.A. \& Pazos-Perez, N. 2018. Surface modifications of nanoparticles for stability in biological fluids. Journal of Materials 11(7): 1-28.

Ismail, H., Shamsudin, R. \& Abdul Hamid, M.A. 2016. Effect of autoclaving and sintering on the formation of $\beta$-wollastonite. Materials Science and Engineering 58: 1077-1081.

Khodabakhshi, M. \& Bahari, A. 2017. Investigation and characterization of maghemite $\left(\gamma-\mathrm{Fe}_{2} \mathrm{O}_{3}\right)$ nanoparticles and its cytotoxicity studies. Indian Journal of Pharmaceutical Education and Research 51: 295-301.

Kokubo, T. 1991. Bioactive glass ceramic: Properties and applications. Biomaterials 12: 155-163.

Laurent, S., Forge, D., Port, M., Roch, A., Robic, C., Elst, L.V. \& Muller, R.N. 2008. Magnetic iron oxide nanoparticles: Synthesis, stabilization, vectorization, physicochemical characterization and biological application. Chem. Rev. 108: 2064-2110.

Lee, Y.L., Wang, W.H., Lin, F.H. \& Lin, C.P. 2017. Hydration behaviors of calcium silicate-based biomaterials. Journal of the Formosan Medical Association 116(6): 424-431.

Li, K., Yu, J., Xie, Y., You, M., Huang, L. \& Zheng, X. 2016. The effects of cerium oxide incorporation in calcium silicate coating on bone mesenchymal stem cell and macrophage responses. Biol. Trace Elem. Res. 174(1): 198-207.

Liu, X., Morra, M., Carpi, A. \& Li, B. 2008. Bioactive calcium silicate ceramics and coatings. Biomedicine \& Pharmacotheraphy 62: 526-529.

Matos, J.C., Goncalves, M.C., Pereira, L.C.J., Vieira, B.J. \& Waerenborgh, J.C. SPIONs prepared in air through improved synthesis methodology: The influence of $\gamma-\mathrm{Fe}_{2} \mathrm{O}_{3} / \mathrm{Fe}_{3} \mathrm{O}_{4}$ ration and coating composition on magnetic properties. Nanomaterial 9(7): 943.

Menon, P.K., Sharma, A., Lafuente, J.V., Muresanu, D.F., Aguilar, Z.P., Wang, A., Patnaik, R., Mossler, H. \& Sharma, H.S. 2017. Intravenous administration of functionalized magnetic iron oxide nanoparticles does not induce CNS injury in the rat: Influence of spinal cord 
trauma and cerebrolysin treatment. International Review of Neurobiology 137: 47-63.

Nazari, M., Ghasemi, N. \& Maddah, H. 2014. Synthesis and characterization of maghemite nanopwders by chemical precipitation method. J. Nanosruct. Chem. 4: 99.

Ngadiman, N.H.A., Idris, A., Muhammad, I., Kurniawan, D., Yusof, N.M. \& Nasiri, R. 2015. $\gamma$ - $\mathrm{Fe}_{2} \mathrm{O}_{3}$ nanoparticles filled polyvinyl alcohol as potential biomaterial for tissue engineering scaffold. Journal of the Mechanical Behaviour of Biomedical Materials 49: 90-104.

Nurdin, I., Johan, M., Yaacob, I., Ang, B. \& Andriyana, A. 2014. Synthesis, characterisation and stability of superparamagnetic maghemite nanoparticle suspension. Mater. Res. Innov. 18: 200-203.

Ohtsuki, C., Kushitani, H., Kokubo, T., Kotani, S. \& Yamamuro, T. 1991. Apatite formation on the surface of Ceravital-type glass-ceramic in the body. J. Biomed. Mater. Res. 25: 13631670.

Rabel, M., Warncke, P., Gruttner, C., Bergemann, C., Kurland, H.D., Muller, R., Dugandzi, V., Thamm, J., Muller, F.A., Popp, J., Cialla-May, D. \& Fischer, D. 2019. Simulation of the long-term fate of superparamagnetic iron oxidebased nanoparticles using simulated biological fluids. Nanomedicine 14(13): 1681-1706.

Shokrollahi, H. 2017. A review of the magnetic properties, synthesis methods and applications of maghemite. Journal of Magnetism and Magnetic Materials 426: 74-81.

Silva, A.K.A., Espinosa, A., Kolosnjaj-Tabi, J., Wilhelm, C. \& Gazeau, F. 2016. Medical applications of iron oxide nanoparticles. In Iron Oxides: From Nature to Applications, edited by Faivre, D. New York: John Wiley \& Sons, Inc. pp. 423-471.

Sun, S.N., Wei, C., Zhu, Z.Z., Huo, Y.L., Subbu, S.V. \& Chuan, X.Z. 2014. Magnetic iron oxide nanoparticles: Synthesis and surface coating techniques for biomedical applications. Chinese Physical Society 23(3): 037503.
Syed Nuzul, F.S.A., Shamsudin, R. \& Firuz, Z. 2016. Synthesis of 60 (wt.) \% $\mathrm{CaO}$ sol-gel derived glass-ceramic and in vitro bioactivity assestment in SBF solution. Key Engineering Materials 673: 161-170.

Wu, W., Xiou, X.H., Zhang, S.F., Peng, T.C., Zhou, J., Ren, F. \& Jiang, C.Z. 2010. Synthesis and magnetic properties of maghemite $\left(\gamma-\mathrm{Fe}_{2} \mathrm{O}_{3}\right)$ short nanotubes. Nanoscale Research Letters 5(9): 1474-1479.

Xie, Y., Li, H., Zhang, C., Gu, X., Zheng, X. \& Huang, L. 2014. Graphene-reinforced calcium silicate coatings for loadbearing implants. Biomedical Materials 9(2): 1-7.

Yu, J., Xu, L., Li, K., Xie, N., Xi, Y, Wang, Y., Zheng, X., Chen, X., Wang, M. \& Ye, X. 2017. Zinc-modified calcium silicate coatings promote osteogenic differentiation through TGF$\beta /$ Smad pathway and osseointegration in osteopenic rabbits. Scientific Reports 7(1): 1-13.

Zamarron, D.R., Hernandez, D.A.C. \& Aragon, L.B. 2009. Mechanical properties and apatite forming ability of PMMA bone cements. Materials and Design 30: 33183324.

Zhu, Y.J., Guo, X.X. \& Sham, T.K. 2016. Calcium silicate-based drug delivery systems. Expert Opinion on Drug Delivery 14(2): 215-228.

School of Applied Physics

Faculty of Science and Technology

Universiti Kebangsaan Malaysia

43600 UKM Bangi, Selangor Darul Ehsan

Malaysia

*Corresponding author; email: insan@ukm.edu.my

Received: 10 September 2019

Accepted: 5 December 2019 